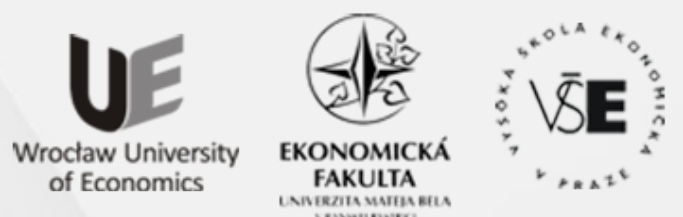

Conference Proceedings

Full TeXT PAPERS

edited by

Zofia Rusnak and Beata Zmyślona

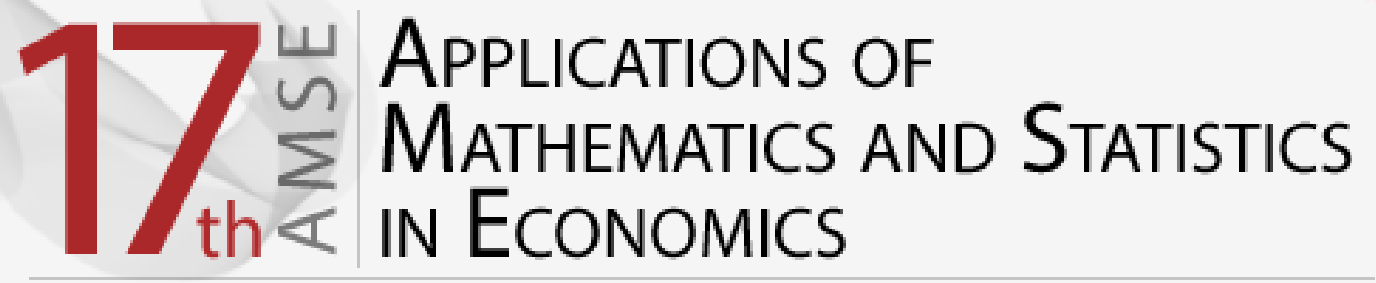

International Scientific Conference | Poland • 27-31 August 2014 
Scientific Committee

Richard Hindls, Stanislava Hronová, Rudolf Zimka, Walenty Ostasiewicz, Emília Zimková, Zofia Rusnak, Martin Bod'a

Organizing Committee

Beata Zmyślona, Cyprian Kozyra, Grzegorz Rogoziński, Kristýna Vltavská

\section{Reviewers}

Milan Bašta, Diana Bílková, Martin Bod'a, Joanna Dębicka, Tomáš Fiala, Jakub Fischer, Stanisław Heilpern, Karel Helman, Lenka Hudrlíková, Miroslav Hužvár, Nikola Kaspř́ková, Alena Kaščáková, Kamil Kladívko, Jindřich Klůfa, Pavol Král', Katarzyna Kuziak, Jana Langhamrová, Ivana Malá, Tomáš Marcinko, Luboš Marek, Miloš Maryška, Petr Mazouch, Zofia Mielecka-Kubień, Witold Miszczak, Petr Musil, Gabriela Nedelová, Walenty Ostasiewicz, Iva Pecáková, Viera Roháčová, Zofia Rusnak, Mária Stachová, Jana Špirková, Šárka Šustová, Jana Tepperová, Vladimír Úradníček, Kristýna Vltavská, Michal Vrabec, Dariusz Wawrzyniak, Henryk Zawadzki, Jaroslav Zbranek, Tomáš Zeithamer, Martin Zelený, Jan Zeman, Rudolf Zimka, Emília Zimková, Pavel Zimmermann, David Žižka

Layout

Martin Bod'a, Beata Zmyślona, Grzegorz Rogoziński

Front page design

Grzegorz Rogoziński

CD cover design

Beata Dębska

Articles published in the form submitted by the authors

All rights reserved. No part of this book may be reproduced in any form or in any means without the prior permission in writing of the Publisher

(C) Copyright by Wrocław University of Economics Wrocław 2014

ISBN 978-83-7695-421-9

Wydawnictwo Uniwersytetu Ekonomicznego we Wrocławiu

53-345 Wrocław, ul. Komandorska 118/120 www.ue.wroc.pl

Sprzedaż książek tel./fax 71 36-80-602

e-mail: econbook@ue.wroc.pl www.ksiegarnia.ue.wroc.pl 


\section{Contents}

Foreword

Diana Bílková: TL-Moments: Analogy of Classical L-Moments

Dagmar Blatná: Application of Robust Regression in the Analysis of Internet Access in European Countries

Martin Bod’a, Mária Kanderová: Rebalancing Issues in Tracking Error Variance Minimization

Martin Bod'a, Viera Roháčová: Application of Six Sigma Ideas to Timing Decisions at Financial Markets

Anton Dekrét, Rudolf Zimka: On the Price Hartwick's Task and Its Inverse in a Dynamic Model of an Economy with Exhaustible Resources

Joanna Dębicka, Agnieszka Marciniuk: Comparison of Reverse Annuity Contract and Reverse Mortgage on the Polish Market.

Petra Dotlačilová, Jitka Langhamrová: The Influence of Mortality Models for the Expected Future Life-time of Older People

Marek Ďurica, Lucia Švábová: Delta and Gamma for Chooser Options.

Vlastimil Farkašovský: New Concept of Pension Funds Performance Evaluation

Albert Gardon: The Normality of Weekly Relative Changes of the Freight Rate in Container Shipping.

Mária Grausová, Miroslav Hužvár, Jana Štrangfeldová: Healthcare Systems Efficiency in the Visegrád Group.

Stanisław Heilpern: Multiple Life Insurance - Pension Calculation

Alena Kaščáková, Gabriela Nedelová: Changes in Slovak Households' Economy

Igor Kollár, Pavol Král', Peter Laco: Methodology for Assessing Website Improvement in Corporate Environment.

Maciej Kostrzewski: Some Method of Detecting the Jump Clustering Phenomenon in Financial Time Series.

Cyprian Kozyra, Beata Zmyślona, Katarzyna Madziarska: Complementary Objective and Subjective Measures of Hospital Services Quality...

Pavol Král', Mária Stachová, Lukáš Sobíšek: Utilization of Repeatedly Measured Financial Ratios in Corporate Financial Distress Prediction in Slovakia

Ivana Malá: The Use of Finite Mixture Model for Describing Differences in Unemployment Duration

Lukáš Malec: Studying Economics and Tourism Industry Relations by Smooth Partial Least Squares Method Depending on Parameter. 
Tomáš Marcinko: Consequences of Assumption Violations Regarding Classical Location Tests.

Edyta Mazurek: The Income Tax Progression Depending on Social Insurance Contribution in Poland.

Petr Musil, Jana Kramulová, Jan Zeman: Regional Consumption Expenditures: An Important Starting Point for Regional Input-output Tables.

Katarzyna Ostasiewicz, Walenty Ostasiewicz: Good Life: From Political to Human Economy

Anna Sączewska-Piotrowska: Analysis of Poverty Transitions in Poland Using Multilevel Discrete-Time Event History Models

Martina Šimková, Petra Švarcová: Disadvantaged University Students in the Czech Republic.

Michal Široký: The Use of Short-term Business Statistics for Quarterly GDP Flash Estimates in the Czech Republic

Zdeněk Šulc, Hana Řezanková: Evaluation of Recent Similarity Measures for Categorical Data.

Lucia Švábová, Marek Ďurica: The Relationship Between the Finite Difference Method and Trinomial Trees

Kristýna Vltavská, Jaroslav Sixta: The Estimation of Final Consumption Expenditures

Lenka Vraná: Business Cycle Analysis: Tracking Turning Points

Janusz Wywiał: On Bayesian Testing in Auditing

Emília Zimková: Window Analysis of Supper-efficiency Change: Case of the Slovak Banking System ....

Beata Zmyślona: Statistical Modelling of the Impact of Diabetes on the Risk of Hospitalization 


\title{
ON THE PRICE HARTWICK'S TASK AND ITS INVERSE IN A DYNAMIC MODEL OF AN ECONOMY WITH EXHAUSTIBLE RESOURCES
}

\author{
ANTON DEKRÉT \\ Cikkerova 11, 97401 Banská Bystrica, Slovakia
}

\begin{abstract}
RUDOLF ZIMKA
Matej Bel University, Faculty of Economics, Department of Quantitative Methods and Information Systems, Tajovského 10, 97590 Banská Bystrica, Slovakia email: Rudolf.zimka@umb.sk
\end{abstract}

\begin{abstract}
Price and generalized price forms of Hartwick's rule play an important role at finding conditions for intergenerational equity with respect to constant consumptions in economies with exhaustible resources. In the paper these price forms of Hartwick's rule are investigated with respect to prices satisfying a special model, which is the price (cotangent) prolongation of the Dasgupta-Heal-Solow-Stiglitz model in the space of price variables. These so called canonical prices enable to solve the price Hartwick's task and its inverse with respect to price equity (the zero value of the price evaluation of the consumption functions change rates), which generalizes the requirement for constant consumptions over time. An example illustrates reached results.
\end{abstract}

Key words: intergenerational equity, exhaustible resource model, price prolonged model, canonical prices, price Hartwick's task, inverse price Hartwick's task.

DOI: $10.15611 / a m s e .2014 .17 .05$

\section{Introduction}

Economies all over the world cannot exist without utilizing precious exhaustible resources. Scientists have been trying to find conditions under which the intergeneration equity can be secured with respect to constant consumption or with respect to constant utility consumption function. The basic result in this domain was gained by Hartwick (1977). He investigated so called the Dasgupta-Heal-Solow-Stiglitz model (the DHSS model; see Dasgupta and Heal (1974), Solow (1974), Stiglitz (1974))

$$
\begin{aligned}
\dot{k} & =f(k, r)-c \equiv F(k, r, c) \\
\dot{s} & =-r,
\end{aligned}
$$

with $n$ variables $k=\left(k_{1}, \ldots, k_{n}\right) \in \mathrm{K}_{\mathrm{n}} \subseteq R_{+}^{n}$ of the renewable capitals in $n$ renewable capital sectors and $m$ variables $s=\left(s_{1}, \ldots, s_{m}\right) \in \mathrm{S}_{\mathrm{m}} \subset R_{+}^{m}$ of the exhaustible resources, $m$ parameters $r=$ $\left(r_{1}, \ldots, r_{m}\right) \in \mathrm{U}_{\mathrm{m}} \subset R_{+}^{m}$ of the extraction rates of the exhaustible resources and $n$ parameters $c=$ $\left(c_{1}, \ldots, c_{n}\right) \in \mathrm{U}_{n} \subset R_{+}^{n}$ of the consumptions in the renewable capital sectors, where $\dot{k}_{i}=\frac{d k_{i}}{d t}, \dot{s}_{j}=$ $\frac{d s_{j}}{d t}$. Hartwick showed that if on a path satisfying the Hotelling rule all the rent from the 


\section{$17 \backsim$ APPLICATIONS OF

exhaustible resource $s$ is used for the accumulation of the renewable capital $k$, then the consumption $c(t)$ is constant over time. This assertion is known as Hartwick's result and its premise as Hartwick's rule. A path $\Omega(t)=(k(t), s(t), r(t), c(t))$ satisfying the DHSS model we call an economic path. Dixit, Hammond and Hoel (1980) expressed the idea of Hartwick's rule by means of the prices $\xi$ and $\Psi$ of the renewable capital $k$ and the exhaustible resource $s$, respectively. They considered multi-dimensional economy with $n$ renewable capitals $k=$ $\left(k_{1}, \ldots, k_{n}\right), m$ exhaustible resources $s=\left(s_{1}, \ldots, s_{m}\right), m$ extraction rates $r=\left(r_{1}, \ldots, r_{m}\right)$, and $n$ consumptions $c=\left(c_{1}, \ldots, c_{n}\right)$. Dixit et all. derived conditions under which the expression $\xi \dot{k}+$ $\psi \dot{s}=E, E$-constant, guarantees constant utility consumption function over time. The expression $\xi \dot{k}+\psi \dot{s}=E, E$-constant, we call the generalized price Hartwick rule (a GPH path). If $E$ is zero, then we call this expression the price Hartwick rule (a PH path). It has come out that Hartwick's rules play an important role in a wider class of problems dealing with the reasonable utilization of exhaustible resources. This can be seen, for example, in the works of Dasgupta and Mitra (1983), Withagen and Asheim(1998), Cairns and Yang (2000), Asheim, Buchholz and Withagen (2003), and Jurča (2010)). The results in these papers put forward a question, what real place Hartwick's rule has in this domain. It follows from the result of Hartwick (1977), that the Hartwick rule is sufficient condition for constant consumption, supposing that Hotelling rule is satisfied. A natural question immediately arises: Is the Hartwick rule also necessary condition for receiving constant consumption? Buchholz, Dasgupta and Mitra (2005) tackled this question, investigating a model with one renewable capital good and one exhaustible resource. They found conditions under which an economic path with constant consumption satisfying the Hotelling rule implicates the Hartwick rule.

The aim of this paper is to contribute to the question what is a real significance of the Hartwick rule in this domain. In the paper we suggest other possibility of expressing the idea of the intergenerational equity in multi-dimensional case. There is introduced a notion of a price equitable path, which is expressed by the requirement, that the price evaluation of the consumption function change rates along an economic path has zero value at each point of time. This notion generalizes the requirement for constant consumptions over time. Besides the notion of the price equitableness there is also introduced a notion of a weak competitiveness This notion represent a weaker form of the notion of the Hotelling rule. The main achieved result is formulated in Theorem. It gives mutual equivalence results among the price equitableness, the generalized Hartwick rule and the weak competitiveness.

\section{Analysis of the Dasgupta-Heal-Solow-Stiglitz model in a multi-dimensional case}

In our considerations we use the Dasgupta-Heal-Solow-Stiglitz model, which we arrange into the form of the following dynamic control system

$$
\begin{aligned}
& \dot{k}_{i}=f^{i}(k, r)-D_{i}\left(k_{i}\right)-c_{i} \equiv F^{i}(k, r, c), \\
& \dot{s}_{j}=-r_{j}, \quad i=1, \ldots, n, \quad j=1, \ldots, m,
\end{aligned}
$$

with $n$ variables $k=\left(k_{1}, \ldots, k_{n}\right) \in \mathrm{K}_{\mathrm{n}} \subseteq R_{+}^{n}$ of the renewable capitals in $n$ renewable capital sectors and $m$ variables $s=\left(s_{1}, \ldots, s_{m}\right) \in \mathrm{S}_{\mathrm{m}} \subset R_{+}^{m}$ of the exhaustible resources, $m$ parameters $r=$ $\left(r_{1}, \ldots, r_{m}\right) \in \mathrm{U}_{\mathrm{m}} \subset R_{+}^{m}$ of the extraction rates of the exhaustible resources and $n$ parameters $c=$ $\left(c_{1}, \ldots, c_{n}\right) \in \mathrm{U}_{n} \subset R_{+}^{n}$ of the consumptions in the renewable capital sectors, where $\dot{k}_{i}=\frac{d k_{i}}{d t}, \dot{s}_{j}=$ $\frac{d s_{j}}{d t}$. The variables $k$ and $s$ are called state variables and the variables $r$ and $c$ are called control variables. Denote the set of all such $(k, r, c)$ by the symbol $M$. The function $f^{i}(k, r)$ is 
production function and the function $D_{i}\left(k_{i}\right)$ is amortization function in the $i^{\text {th }}$ renewable capital sector, $i=1, \ldots, n$. We assume that all functions in system (1) are differentiable up to the second order on the set $M$, the production functions $\mathrm{f}^{\mathrm{i}}(\mathrm{k}, \mathrm{r})$ are increasing and concave on $M$ with respect to $k$ and $r, f^{i}(0, r)=f^{i}(k, 0)=0, f^{i}(k, r)>0$ for $k>0, r>0$. Further we assume that to each function $f^{i}(k, r)$ there exists a variable $r_{p}, p \in\{1, \ldots, m\}$, such that $f^{i}\left(k, r_{1}, \ldots, r_{p-1}, r_{p}=\right.$ $\left.0, \mathrm{r}_{\mathrm{p}+1}, \ldots, \mathrm{r}_{\mathrm{m}}\right)=0, i=1, \ldots, n$, (this means that the resource $\mathrm{r}_{\mathrm{p}}$ is important in production), and $\mathrm{r}_{\mathrm{j}}<S_{j}^{0}$ for $t \geq 0, j=1, \ldots, m, S_{j}^{0}$ - the quantity of the $j^{t h}$ exhaustible resource at the beginning, $S^{0}=\left(S_{1}^{0}, \ldots, S_{m}^{0}\right)$.

In our further considerations we will work only with the open sets $K_{n}, S_{m}, U_{n}, U_{m}$, while the sets $S_{m}, U_{n}, U_{m}$ are bounded in their corresponding spaces. Let $r(t)=\left(r_{1}(t), \ldots, r_{m}(t)\right)$ be an arbitrary path in $U_{m}$, satisfying the condition that $\int_{0}^{\infty} r_{j}(t) d t \leq S_{j}^{0}$ (then $\lim _{t \rightarrow \infty} r_{j}(t)=0$; therefore $\left.\inf _{t \geq 0} r_{j}(t)=0.\right)$, and $c(t)=\left(c_{1}(t), \ldots, c_{n}(t)\right)$ be an arbitrary path in $\mathrm{U}_{\mathrm{n}}$. A curve $\varepsilon(\mathrm{t})=(\mathrm{r}(\mathrm{t}), \mathrm{c}(\mathrm{t}))$ is called a control path. Let $\omega(\mathrm{t})=(\mathrm{k}(\mathrm{t})>0, \mathrm{~s}(\mathrm{t})>0)$ be the solution of the system (1) corresponding to the control path $\varepsilon(\mathrm{t})$ and to the initial values $\mathrm{k}(0)=\mathrm{k}_{0}>0, \mathrm{~s}(0)=\mathrm{s}_{0}>0$. The path $\Omega(t)=(\omega(\mathrm{t}), \varepsilon(\mathrm{t}))$ is called an economic path.

Consider now the cotangent prolongation of the system (1)

$$
\begin{array}{ll}
\dot{\mathrm{k}}_{\mathrm{i}}=\mathrm{F}^{\mathrm{i}}(\mathrm{k}, \mathrm{r}, \mathrm{c})=\frac{\partial \mathrm{H}}{\partial \xi_{\mathrm{i}}}, & \dot{\xi}_{\mathrm{i}}=-\frac{\partial \mathrm{H}}{\partial \mathrm{k}_{\mathrm{i}}}, \quad \mathrm{i}=1, \ldots, \mathrm{n}, \\
\dot{\mathrm{s}}_{\mathrm{j}}=-\mathrm{r}_{\mathrm{j}}=\frac{\partial \mathrm{H}}{\partial \psi_{\mathrm{j}}}, & \dot{\Psi}_{\mathrm{j}}=-\frac{\partial \mathrm{H}}{\partial \mathrm{s}_{\mathrm{j}}}, \quad \mathrm{j}=1, \ldots, \mathrm{m} .
\end{array}
$$

where $\mathrm{H}=\mathrm{H}(\mathrm{k}, \mathrm{s}, \mathrm{r}, \mathrm{c}, \xi, \psi)=\xi \dot{\mathrm{k}}+\psi \dot{\mathrm{s}}=\sum_{\mathrm{i}=1}^{\mathrm{n}} \xi_{\mathrm{i}} \mathrm{F}^{\mathrm{i}}(\mathrm{k}, \mathrm{r}, \mathrm{c})-\sum_{\mathrm{j}=1}^{\mathrm{m}} \psi_{\mathrm{j}} \mathrm{r}_{\mathrm{j}}$ is Hamiltonian of the system (1) (we refer our readers to Yano and Ishihara (1973) for details). We see that formally Hamiltonian has the form of the left-hand side of the price forms of the Hartwick rule. Therefore we can look at the co-variables $\xi=\left(\xi_{1}, \ldots, \xi_{n}\right), \psi=\left(\psi_{1}, \ldots, \psi_{m}\right)$ as the prices of the renewable capitals $k=\left(k_{1}, \ldots, k_{n}\right)$ and the exhaustible resources $s=\left(s_{1}, \ldots, s_{m}\right)$, respectively. Therefore we can call this cotangent prolongation as the price prolongation of the DasguptaHeal-Solow-Stiglitz model.

Consider an economic path $\Omega(t)=(\omega(\mathrm{t}), \varepsilon(\mathrm{t}))$ and an arbitrary pair of prices $(\xi(\mathrm{t}), \psi(\mathrm{t})), \xi(\mathrm{t})>0, \psi(\mathrm{t})>0, t \geq 0$. A vector function $\Omega^{q}(t)=(\omega(\mathrm{t}), \varepsilon(\mathrm{t}), \xi(\mathrm{t}), \psi(\mathrm{t}))$ we call a price economic path. If these prices $(\xi(\mathrm{t}), \psi(\mathrm{t})), \xi(\mathrm{t})>0, \psi(\mathrm{t})>0, t \geq 0$, satisfy system (2), then a vector function $(\omega(\mathrm{t}), \varepsilon(\mathrm{t}), \xi(\mathrm{t}), \psi(\mathrm{t}))$ we call a price canonical economic path and denote it by the symbol $\Omega^{p}(t)$.The formal equivalence between Hamiltonian and the left-hand side of the price forms of Hartwick's rule enable us to define the notions of a generalized price Hartwick path and a price Hartwick path, which were established in Introduction, also for Hamiltonian.

Definition 1. We say that a price economic path $\Omega^{q}(t)$ is a generalized price Hartwick path (a GPH path), if Hamiltonian has along $\Omega^{q}(t)$ the property $H\left(\Omega^{q}(t)\right)=H_{0}, H_{0}$-constant. If $H_{0}=$ 0 then we say that $\Omega^{q}(t)$ is a price Hartwick path (a PH path).

Definition 2. Consider an economic path $\Omega(t)=(k(t), s(t), r(t), c(t))$. We say that $\Omega(t)$ is equitable path, if $c_{i}(t)=c_{i}^{0}$-constant, $c_{i}^{0}>0, t \geq 0, i=1, \ldots n$. 


\section{APPLICATIONS OF

Definition 3. Consider a price economic path $\Omega^{q}(t)$. We say that $\Omega^{q}(t)$ is price equitable, if $\sum_{i=1}^{n} \xi_{i} \dot{c}_{i}=0$,

Remark 1. The notion a price equitable path generalizes the notion an equitable path. It seems that the notion a price equitable path can better describe changing ideas of persons or generations about what kinds of products and services bring them the feeling of a good satisfaction, maintaining at the same time the level of satisfaction approximately at constant value over time. For example a young person receives a greater satisfaction from buying fashion clothes, sport cars, etc., meanwhile an older person utilizes an allocated budget for buying health food, medicine, etc.

Let us differentiate Hamiltonian $\mathrm{H}(\mathrm{k}, \mathrm{s}, \mathrm{r}, \mathrm{c}, \xi, \psi)=\sum_{\mathrm{i}=1}^{\mathrm{n}} \xi_{\mathrm{i}} \mathrm{F}^{\mathrm{i}}(\mathrm{k}, \mathrm{r}, \mathrm{c})-\sum_{\mathrm{j}=1}^{\mathrm{m}} \psi_{\mathrm{j}} \mathrm{r}_{\mathrm{j}}$ with respect to time on a price canonical economic path $\Omega^{p}(t)$. Utilizing system (2) we get

$$
\frac{d H\left(\Omega^{p}(t)\right)}{d t}=\sum_{j=1}^{m} \frac{\partial H}{\partial \mathrm{r}_{j}} \dot{r}_{j}+\sum_{i=1}^{n} \frac{\partial H}{\partial c_{i}} \dot{c}_{i}
$$

As $\frac{\partial H\left(\Omega^{p}(t)\right)}{\partial \mathrm{r}_{j}}=\sum_{i=1}^{n} \xi_{i} \frac{\partial F^{i}}{\partial r_{j}}-\psi_{j}$, and $\frac{\partial H\left(\Omega^{p}(t)\right)}{\partial c_{i}}=-\xi_{i}$, we receive from (3)

$$
\frac{d H\left(\Omega^{p}(t)\right)}{d t}=\sum_{j=1}^{m}\left(\sum_{i=1}^{n} \xi_{i} \frac{\partial F^{i}}{\partial r_{j}}-\psi_{j}\right) \dot{r}_{j}-\sum_{i=1}^{n} \xi_{i} \dot{c}_{i}
$$

Remark 2. If the prices $\xi, \psi$ are not canonical, then the expression $\frac{\mathrm{dH}\left(\Omega^{\mathrm{p}}(\mathrm{t})\right)}{\mathrm{dt}}$ is essentially different from that in (4).

Definition 4. Consider a path $\Omega^{q}(t)$ which need not be canonical. If $\frac{\partial H\left(\Omega^{q}(t)\right)}{\partial r_{j}}=0, j=1, \ldots, m, w e$ say that the path $\Omega^{q}(t)$ is resource stationary (r-stationary). If $\frac{\partial H\left(\Omega^{q}(t)\right)}{\partial r_{j}}=$ constant, $j=1, \ldots, m$, we say that the path $\Omega^{q}(t)$ is resource equisloped (r-equisloped). If $\sum_{j=1}^{m} \frac{\partial H\left(\Omega^{q}(t)\right)}{\partial r_{j}} \dot{r}_{j}=0$, we say that the path $\Omega^{q}(t)$ is resource stabilized (r-stabilized).

\section{Remark 3.}

1. We see that if a path $\Omega^{\mathrm{q}}(\mathrm{t})$ is $\mathrm{r}$-stationary, then it is also r-stabilized. In the case $\mathrm{m}=1$, and $\dot{\mathrm{r}} \neq 0$, there holds that if $\Omega^{\mathrm{q}}(\mathrm{t})$ is $\mathbf{r}$-stabilized then it is also $\mathbf{r}$-stationary.

2. A path $\Omega^{\mathrm{q}}(\mathrm{t})$ is $r$-stationary if and only if it satisfies the condition

$$
\sum_{i=1}^{n} \xi_{i} \frac{\partial F^{i}}{\partial r_{j}}-\psi_{j}=0, j=1, \ldots, m
$$

i.e. if and only if the price of the unit of the $\mathbf{j}$-source is equal to the evaluation of the production increments provided by the unit of $\mathbf{j}$-source, $j=1, \ldots \mathrm{m}$. It gives the system of linear equations with respect to $\xi_{\mathrm{i}}, \mathrm{i}=1, \ldots, \mathrm{n}$, supposing that $\psi_{\mathrm{j}}, \mathrm{j}=1, \ldots, \mathrm{m}$, are given. Its solution need not be canonical, i.e. it need not be a solution of system (2). Since $\Omega^{\mathrm{q}}(\mathrm{t})=(\Omega(\mathrm{t}), \xi(\mathrm{t}), \psi(\mathrm{t}))$ is 


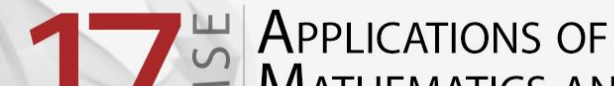

a price economic path $(\Omega(t)=(\omega(t), \varepsilon(t))$ satisfies system (1)), we can look at relation (5) as on the task to find to given $\Omega(\mathrm{t})$ such prices $\xi(\mathrm{t}), \psi(\mathrm{t})$ to get resource stationary $\Omega^{\mathrm{q}}(\mathrm{t})$.

From relation (4) there immediately follows

Theorem. If a price canonical economic path $\Omega^{p}(t)$ has any two of the following three properties:

a) it is generalized price Hartwick path,

b) it is price equitable,

c) it is resource stabilized,

then it has also the remaining property.

Consequence of Theorem. If a price canonical economic path $\Omega^{p}(t)$ is resource stabilized, then it is generalized price Hartwick path if and only if it is price equitable.

This means that in the case of a price canonical economic path $\Omega^{\mathrm{p}}(\mathrm{t})$ the property ${ }_{,} \Omega^{\mathrm{p}}(\mathrm{t})$ is resource stabilized" is a sufficient condition for a generalized price Harwick path to be price equitable and also for its inverse.

We see that Theorem gives a sufficient condition for a price canonical economic path $\Omega^{\mathrm{p}}(\mathrm{t})$ along which the property to be the generalized price Harwick path is necessary and sufficient for to be price equitable. If we want to receive similar result with respect to the property of a price canonical economic path $\Omega^{\mathrm{p}}(\mathrm{t})$ to be the price Harwick path we need to derive conditions under which a generalized price Harwick path is a price Harwick path. The following two propositions give answer to this task.

Definition 5. We say that a price economic path $\Omega^{q}(t)$ has the property $\theta$, if $\inf _{\Omega^{q}(t)} \sum_{i=1}^{n} \xi_{i} f^{i}\left(\Omega^{q}(t)\right)=\vartheta>0$.

If a path $\Omega^{q}(t)$ has the property $\theta$, then Hamiltonian $\mathrm{H}(\mathrm{k}, \mathrm{s}, \mathrm{r}, \mathrm{c}, \xi, \psi)$ can be expressed on the path $\Omega^{q}(t)$ in the form

$$
\begin{gathered}
\mathrm{H}\left(\Omega^{q}(t)\right)=\sum_{i=1}^{m} \xi_{i} \mathrm{f}^{\mathrm{i}}\left[1-\frac{\sum_{i=1}^{m} \xi_{i}\left(D_{i}+c_{i}\right)+\sum_{\mathrm{j}=1}^{\mathrm{m}} \psi_{\mathrm{j}} \mathrm{r}_{\mathrm{j}}}{\sum_{i=1}^{m} \xi_{i} \mathrm{f}^{\mathrm{i}}}\right]=\sum_{i=1}^{m} \xi_{i} \mathrm{f}^{\mathrm{i}}[1-P(t)] \\
\mathrm{P}(t)=\frac{\sum_{i=1}^{m} \xi_{i}\left(D_{i}+c_{i}\right)+\sum_{\mathrm{j}=1}^{\mathrm{m}} \psi_{\mathrm{j}} \mathrm{r}_{\mathrm{j}}}{\sum_{i=1}^{m} \xi_{i} \mathrm{f}^{\mathrm{i}}}
\end{gathered}
$$

We see that if a path $\Omega^{q}(t)$ has the property $\theta$ and $P\left(\Omega^{q}(t)\right)>1$, or $\mathrm{P}\left(\Omega^{q}(t)\right)<1$, or $\mathrm{P}\left(\Omega^{q}(t)\right)=1$, then $\mathrm{H}\left(\Omega^{q}(t)\right)<0$, or $\mathrm{H}\left(\Omega^{q}(t)\right)>0$, or $\mathrm{H}\left(\Omega^{q}(t)\right)=0$, respectively.

Proposition 1. Let $\Omega^{q}(t)$ be a GPH path with the property $\theta$. If a) $\inf _{\Omega^{q}(t)} P\left(\Omega^{q}(t)\right)=1$ or b) $\sup _{\Omega^{q}(t)} H(k, s, \xi, \psi, r, c)=1$ or $\left.c\right)$ there exists $t_{1}$ such that $P\left(\Omega^{q}\left(t_{1}\right)\right)=1$, then $H\left(\Omega^{q}(t)\right)=H_{0}=0$, i.e. $\Omega^{q}(t)$ is a PH path. 


\section{APPLICATIONS OF

Proof. a) According to the assumption of Proposition 1 there is $\mathrm{P}\left(\Omega^{q}(t)\right) \geq 1$, and consequently $\mathrm{H}\left(\Omega^{q}(t)\right)=H_{0} \leq 0$. From this assumption it also follows that there does not exist $\varepsilon>0$ such that $\mathrm{P}\left(\Omega^{q}(t)\right)=\frac{\sum_{i=1}^{m} \xi_{i}\left(D_{i}+c_{i}\right)+\sum_{j=1}^{\mathrm{m}} \psi_{\mathrm{j}} \mathrm{r}_{\mathrm{j}}}{\sum_{i=1}^{m} \xi_{i} \mathrm{i}^{\mathrm{i}}} \geq 1+\varepsilon$ for $t \geq 0$. From this we have $\sum_{i=1}^{m} \xi_{i}\left(D_{i}+c_{i}\right)+$ $\sum_{\mathrm{j}=1}^{\mathrm{m}} \psi_{\mathrm{j}} \mathrm{r}_{\mathrm{j}} \geq \sum_{i=1}^{m} \xi_{i} \mathrm{f}^{\mathrm{i}}+\varepsilon \sum_{i=1}^{m} \xi_{i} \mathrm{f}^{\mathrm{i}^{i}}$, and from this $-\varepsilon \sum_{i=1}^{m} \xi_{i} \mathrm{f}^{\mathrm{i}} \geq \sum_{i=1}^{m} \xi_{i} \mathrm{f}^{\mathrm{i}}-\sum_{i=1}^{m} \xi_{i}\left(D_{i}+c_{i}\right)-$ $\sum_{j=1}^{m} \psi_{j} r_{j}=$

$\mathrm{H}\left(\Omega^{q}(t)\right)$. We see that there does not exist $\varepsilon>0$ such that $-\varepsilon \sum_{i=1}^{m} \xi_{i} \mathrm{f}^{\mathrm{i}} \geq \mathrm{H}\left(\Omega^{q}(t)\right)$. Thus we get $\mathrm{H}\left(\Omega^{q}(t)\right) \leq-\varepsilon \vartheta$, as $\Omega^{q}(t)$ has the property $\theta$. We see that there does not exist a number $\alpha=\varepsilon \vartheta>$ 0 such that $\mathrm{H}\left(\Omega^{q}(t)\right) \leq-\alpha$. This means that there cannot be $\mathrm{H}\left(\Omega^{q}(t)\right)<0$. As $\mathrm{H}\left(\Omega^{q}(t)\right) \leq 0$, we get $\mathrm{H}\left(\Omega^{q}(t)\right)=H_{0}=0$. The case $\left.\mathrm{b}\right)$ can be proved analogously. The case $\left.\mathrm{c}\right)$ is evident.

Definition 6. We say that a price economic path $\Omega^{q}(t)$ has the property $\Sigma$, if there exists $j \in$ $\{1, \ldots, m\}$ and $\sigma>0$ such that on the path $\Omega^{q}(t)$ there is $\frac{\frac{\partial f^{i}}{\partial r_{j}} r_{j}}{f^{i}} \geq \sigma$ for $t \geq 0, i=1, \ldots, n$.

Consider $K(t)=\xi(t) k(t)+\psi(t) s(t)=\sum_{i=1}^{n} \xi_{i} k_{i}+\sum_{j=1}^{m} \psi_{j} s_{j}$. By our assumptions $K(t) \geq 0$, $\frac{\partial f^{p}}{\partial k_{i}}>0, i, p=1, \ldots, n$. The following considerations were inspired by Jurča (2010, PhD Thesis, The section 4.4).

Lemma 1. Suppose that the amortization $D_{i}=0, i=1, \ldots, n$. If a price canonical economic path $\Omega^{p}(t)$ is a GPH path, then $H\left(\Omega^{p}(t)\right)=H_{0} \geq 0$.

Proof. Suppose that $H_{0}<0$. Differentiating $K(t)$ with respect to time, we receive $\frac{d K(t)}{d t}=\dot{\xi} k+\xi \dot{k}+\dot{\psi} s+\psi \dot{s}=\sum_{i=1}^{n} \dot{\xi}_{i} k_{i}+\sum_{i=1}^{n} \xi_{i} F^{i}-\sum_{j=1}^{m} \psi_{j} r_{j}=H_{0}+\sum_{i=1}^{n} \dot{\xi}_{i} k_{i}$.

From this, utilizing that $\dot{\xi}_{i}=-\frac{\partial H}{\partial k_{i}}=-\sum_{p=1}^{n} \xi_{p} \frac{\partial F}{\partial k_{i}}$, we get $\frac{d K(t)}{d t}=H_{0}--\sum_{i=1}^{n} \sum_{p=1}^{n} \xi_{p} \frac{\partial f^{p}}{\partial k_{i}} k_{i}<0$.

Therefore $K(t)$ is decreasing, and $\lim _{t \rightarrow \infty} \frac{d K(t)}{d t} \leq H_{0}<0$. This means that there exists $t_{1}$ such that $K(t)<0$ for $t>t_{1}$. This contradicts the assumption that $K(t) \geq 0$. Therefore $H_{0} \geq 0$.

Lemma 2. Let a path $\Omega^{q}(t)$ be an r-stationary GPH path with the property $\Sigma$. If $H\left(\Omega^{q}(t)\right) \geq 0$, then $H\left(\Omega^{q}(t)\right)=0$, i.e. $\Omega^{q}(t)$ is a PH path.

Proof. By the assumption there is $H\left(\Omega^{q}(t)\right)=H_{0} \geq 0$. We show that it cannot be $H_{0}>0$. Let $H_{0}>0$. Then by the property $\Sigma$ and $r$-stationarity there is $\frac{\psi_{j} r_{j}}{\sigma}=\sum_{i=1}^{n} \xi_{i} \frac{\partial f^{i}}{\partial r_{j}} \frac{r_{j}}{\sigma} \geq \sum_{i=1}^{n} \xi_{i} f^{i}=$ $\sum_{i=1}^{n} \xi_{i}\left(\dot{k}_{i}+D_{i}\left(k_{i}\right)+c_{i}\right) \geq \sum_{i=1}^{n} \xi_{i} \dot{k}_{i}=H_{0}+\sum_{j=1}^{m} \psi_{j} r_{j} \geq H_{0}$. From this we have $\frac{\psi_{j} r_{j}}{\sigma} \geq H_{0}>0$, and $r_{j} \geq \frac{\sigma}{\psi_{j}} H_{0}>0$, as $\psi_{j}=\psi_{0 j}>0$. This contradicts the assumption that $\int_{0}^{\infty} r(t) d t<\infty$. Therefore $H_{0}=0$.

Proposition 2. Let a price canonical economic path $\Omega^{p}(t)$ be an $r$-stationary GPH path with the property $\Sigma$ without amortization. Then $H\left(\Omega^{p}(t)\right)=0$, i.e. $\Omega^{p}(t)$ is a PH path.

Proof. By Lemma 1 there is $H_{0} \geq 0$. Then by Lemma 2 there is $H_{0}=0$. 
Example. Consider system (1) for the case $n=1, m=1$ with Cobb-Douglas function $f(k, r)=$ $\gamma k^{\alpha} r^{\beta}$ and $D(k)=0, \alpha>0, \beta>0, \gamma>0, \alpha+\beta \leq 1$. Take a control path $\varepsilon(\mathrm{t})=(\mathrm{r}(\mathrm{t}), \mathrm{c}(\mathrm{t}))$ with $r(t)=v\left(k_{0}+u t\right)^{-\frac{\alpha}{\beta}}, c(t)=c_{0}-$ constant, $k_{0}>0, u>0, v>0$. By direct calculation it can be found that the functions $\omega(\mathrm{t})=(\mathrm{k}(\mathrm{t}), \mathrm{s}(\mathrm{t})), k(t)=k_{0}+u t, s(t)=s_{0}-\int_{0}^{t} v\left(k_{0}+u \tau\right)^{-\frac{\alpha}{\beta}} \mathrm{d} \tau$ are the solutions of system (1) with the initial values $k_{0}, s_{0}$, corresponding to given control path $\varepsilon(\mathrm{t})$ if and only if the values $u, v, c_{0}$ and the parameters $\beta, \gamma$ are joined together by the relation $u=\gamma v^{\beta}-c_{0}$. This means that $\Omega(t)=(\omega(\mathrm{t}), \varepsilon(\mathrm{t}))$ is economic path of system (1).

The price prolongation of system (1) is

$$
\begin{array}{ll}
\dot{k}=\frac{\partial \mathrm{H}}{\partial \xi}=\gamma k^{\alpha} r^{\beta}-c_{0}, & \dot{\xi}=-\frac{\partial \mathrm{H}}{\partial \mathrm{k}}=-\xi \alpha \gamma k^{\alpha-1} r^{\beta}, \\
\dot{s}=\frac{\partial \mathrm{H}}{\partial \psi}=-\mathrm{r}, & \dot{\psi}=-\frac{\partial \mathrm{H}}{\partial \mathrm{s}}=0,
\end{array}
$$

where $\mathrm{H}=\mathrm{H}(\mathrm{k}, \mathrm{s}, \xi, \psi, \mathrm{r}, \mathrm{c})=\xi \dot{\mathrm{k}}+\psi \dot{\mathrm{s}}=\xi\left(\gamma k^{\alpha} r^{\beta}-c_{0}\right)-\psi \mathrm{r}$. Solutions $\xi(t), \psi(t)$ of $(6)$, corresponding to the economic path $\Omega(t)$ are given by the equations

$$
\dot{\xi}=-\frac{\partial \mathrm{H}}{\partial \mathrm{k}}=-\xi \alpha \gamma\left(k_{0}+u t\right)^{\alpha-1} v^{\beta}\left(k_{0}+u t\right)^{-\alpha}=-\xi \alpha \gamma v^{\beta}\left(k_{0}+u t\right)^{-1}, \quad \dot{\psi}=0 .
$$

Their solutions, which are determined by the initial values $\xi_{0}, \psi_{0}$, have the form

$$
\xi(t)=\xi_{0} k_{0}^{\frac{\alpha \gamma v^{\beta}}{u}}\left(k_{0}+u t\right)^{-\frac{\alpha \gamma v^{\beta}}{u}}, \quad \psi(t)=\psi_{0}
$$

Then the path $\Omega^{p}(t)=(\omega(\mathrm{t}), \varepsilon(\mathrm{t}), \xi(\mathrm{t}), \psi(\mathrm{t}))$ with $k(t)=k_{0}+u t, s(t)=s_{0}-\int_{0}^{t} v\left(k_{0}+u \tau\right)^{-\frac{\alpha}{\beta}} \mathrm{d} \tau$, $r(t)=v\left(k_{0}+u t\right)^{-\frac{\alpha}{\beta}}, \mathrm{c}(t)=c_{0}, \xi(t)=\xi_{0} k_{0}^{\frac{\alpha \gamma v^{\beta}}{u}}\left(k_{0}+u t\right)^{-\frac{\alpha \gamma v^{\beta}}{u}}, \psi(t)=\psi_{0}, u=\gamma v^{\beta}-c_{0}$, is the price canonical economic path.

Let us investigate some properties of this price canonical economic path $\Omega^{p}(t)$.

a) The property $\theta$ (Definition 5): $\inf _{\Omega^{p}(t)} \sum_{i=1}^{m} \xi_{i} \mathrm{f}^{\mathrm{i}}\left(\Omega^{p}(t)\right)=\vartheta>0$.

There is $\inf _{\Omega^{p}(t)} \xi_{0} k_{0}^{\frac{\alpha \gamma v^{\beta}}{u}}\left(k_{0}+u t\right)^{-\frac{\alpha \gamma v^{\beta}}{u}} \gamma\left(k_{0}+u t\right)^{\alpha}\left(v\left(k_{0}+u t\right)^{-\frac{\alpha}{\beta}}\right)^{\beta}=\inf _{\Omega^{p}(t)} \xi_{0} \gamma v^{\beta} k_{0}^{\frac{\alpha \gamma v^{\beta}}{u}}\left(k_{0}+u t\right)^{-\frac{\alpha \gamma v^{\beta}}{u}}=0$.

This means that the path $\Omega^{p}(t)$ does not have the property $\theta$.

b) The property $\Sigma$ (Definition 6): On the path $\Omega^{p}(t)$ there is $\frac{\frac{\partial f^{i}}{\partial r_{j}} r_{j}}{f^{i}} \geq \sigma>0$.

As $\frac{\frac{\partial f^{i}}{\partial r_{j}} r_{j}}{f^{i}}=\beta>0$, the path $\Omega^{p}(t)$ has the property $\Sigma$.

Let us find conditions under which the considered path $\Omega^{p}(t)$ will be $r$-stabilized GPH path. According to Definition 4 the path $\Omega^{p}(t)$ will be resource stabilized if along this path $\sum_{j=1}^{m} \frac{\partial H\left(\Omega^{p}(t)\right)}{\partial \mathrm{r}_{j}} \dot{r}_{j}=0$, i.e. $\frac{\partial H\left(\Omega^{p}(t)\right)}{\partial r} \dot{r}=0$. Supposing $\dot{r} \neq 0$, the path $\Omega^{p}(t)$ will be resource stabilized if and only if $\frac{\partial H\left(\Omega^{p}(t)\right)}{\partial r}=0$, that is if and only if it is $r$-stationary. This gives $\xi \gamma \beta k^{\alpha} r^{\beta-1}-\psi=0$, and 


\section{APPLICATIONS OF

$$
\xi_{0} k_{0}^{\frac{\alpha \gamma v^{\beta}}{u}}\left(k_{0}+u t\right)^{-\frac{\alpha \gamma v^{\beta}}{u}} \gamma \beta\left(k_{0}+u t\right)^{\alpha}\left(v\left(k_{0}+u t\right)^{-\frac{\alpha}{\beta}}\right)^{\beta-1}=\Psi_{0} .
$$

From this we have $\xi_{0} k_{0}^{\frac{\alpha \gamma v^{\beta}}{u}} \gamma \beta v^{\beta-1}\left(k_{0}+u t\right)^{\frac{\alpha}{\beta}-\frac{\alpha \gamma v^{\beta}}{u}}=\psi_{0}$. This will be satisfied if and only if $\frac{\alpha}{\beta}-$ $\frac{\alpha \gamma v^{\beta}}{u}=0, \xi_{0} k_{0}^{\frac{\alpha v v^{\beta}}{u}} \gamma \beta v^{\beta-1}=\psi_{0}$. We have found that the price canonical economic path $\Omega^{p}(t)$ is $r$ stationary and also $r$-stabilized if and only if the following conditions are satisfied:

$$
u=\gamma v^{\beta}-c_{0}, \quad \frac{\alpha}{\beta}-\frac{\alpha \gamma v^{\beta}}{u}=0, \quad \xi_{0} k_{0}^{\frac{\alpha \gamma v^{\beta}}{u}} \gamma \beta v^{\beta-1}=\psi_{0}
$$

As $c(t)=c_{0}$, the path $\Omega^{p}(t)$ is price equitable. According to Theorem the path $\Omega^{p}(t)$ is the GPH path, if conditions (7) are satisfied. Because $\Omega^{p}(t)$ has the property $\Sigma$ and $D(k)=0$, we get in the power of Proposition 2 that $\Omega^{p}(t)$ is also the $P H$ path. This assertion can be confirmed by direct calculation too. We have

$$
\begin{aligned}
& H\left(\Omega^{p}(t)\right)=\xi\left(\gamma k^{\alpha} r^{\beta}-c_{0}\right)-\psi \mathrm{r}=\xi_{0} k_{0}^{\frac{\alpha \gamma v^{\beta}}{u}}\left(k_{0}+u t\right)^{-\frac{\alpha \gamma v^{\beta}}{u}} \\
& \left(\gamma\left(k_{0}+u t\right)^{\alpha}\left(v\left(k_{0}+u t\right)^{-\frac{\alpha}{\beta}}\right)^{\beta}-c_{0}\right)-\psi_{0} v\left(k_{0}+u t\right)^{-\frac{\alpha}{\beta}}= \\
& \left(k_{0}+u t\right)^{-\frac{\alpha}{\beta} \xi_{0} k_{0}^{\frac{\alpha \gamma v^{\beta}}{u}}}\left(k_{0}+u t\right)^{\frac{\alpha}{\beta}-\frac{\alpha \gamma v^{\beta}}{u}}\left(\gamma v^{\beta}-c_{0}\right)-\psi_{0} v\left(k_{0}+u t\right)^{-\frac{\alpha}{\beta}} \text {, }
\end{aligned}
$$

and from this

$$
H\left(\Omega^{p}(t)\right)=\left(k_{0}+u t\right)^{-\frac{\alpha}{\beta}}\left(\xi_{0} k_{0}^{\frac{\alpha \gamma v^{\beta}}{u}}\left(k_{0}+u t\right)^{\frac{\alpha}{\beta}-\frac{\alpha \gamma v^{\beta}}{u}}\left(\gamma v^{\beta}-c_{0}\right)-\psi_{0} v\right) .
$$

Utilizing conditions (7), we get $\xi_{0} k_{0}^{\frac{\alpha \gamma v^{\beta}}{u}}\left(k_{0}+u t\right)^{\frac{\alpha}{\beta}-\frac{\alpha \gamma v^{\beta}}{u}}\left(\gamma v^{\beta}-c_{0}\right)-\psi_{0} v=0$, what means that $H\left(\Omega^{p}(t)\right)=0$, i.e. $\Omega^{p}(t)$ is the $P H$ path.

\section{Conclusion}

Scientists have been trying to clear up what real role Hartwick's rules play in the domain of finding conditions which would guarantee the intergenerational equity in economies with exhaustible resources. So far under the intergenerational equity there has been understood constant consumption or constant utility consumption function over time. In this paper there is introduced a new look on the intergenerational equity expressed by the notion of price equity (Definition 3). This notion generalizes the notion of constant consumption. Besides this notion there are also introduced the notions of the generalized price Hartwick rule and the price Hartwick rule (Definition 1), and the notion of resource stability (Definition 4). The main achieved result is formulated in Theorem. It gives mutual equivalence results among the price equitableness, the generalized Hartwick rule and the resource stability. The assertion of Theorem contributes to clearing what is a real significance of Hartwick's rules as it contains in itself also the result that if a price canonical economic path is resource stabilized, then its 


\section{APPLICATIONS OF

property to be the generalized price Hartwick path is necessary and sufficient for being the price equitable path. Propositions 1 and 2 give sufficient conditions under which the assertion of Theorem is valid with respect to the price Hartwick path. Example in the end illustrates the reached results.

\section{Acknowledgments}

This work was elaborated in the frame of a project Dynamic of macroeconomic processes in open economies, supported by the Slovak grant agency VEGA, No. 1/1276/12.

\section{References}

1. ASHEIM, G.B., BUCHHOLZ, W., WITHAGEN, C. 2003. The Hartwick Rule: Myth and Facts. Environmental and Resource Economics, Vol. 25, 129-150.

2. BUCHHOLZ, W., DASGUPTA, S., MITRA, T. 2005. Intertemporal Equity and Hartwick's rule in an Exhaustible Resource Model. Scand. J. of Economics 107 (3), $547-$ 561.

3. CAIRNS, R.D., YANG, Z. 2000. The converse of the Hartwick's Rule and Uniqueness of the Sustainable Path. Natural Resource Modeling, Vol. 13, No. 4, 493-502.

4. DASGUPTA, P., HEAL, G. 1974. The Optimal Depletion of Exhaustible Resources. The Review of Economic Studies, Vol. 41, (symposium issue), 3-28.

5. DASGUPTA, P., MITRA, T. 1983. Intergenerational Equity and Efficient Allocation of Exhaustible Resources, Intl. Econ Rev. 24, 133-153.

6. DIXIT, A., HAMMOND, P., HOEL, Hoel, M. 1980. On Hartwick's Rule for Regular Maximin Paths of Capital Accumulation and Resource Depletion. The Review of Economic Studies, Vol. 47, No. 3, 551-556.

7. HARTWICK, J. M. 1977. Intergenerational Equity and the Investing of Rents from Exhaustible Resources. The American Economic Revue, Vol. 67, No. 5, 972-974.

8. JURČA, P. 2010. Sustainability in Models of Optimal Economic Growth. PhD Thesis, Faculty of Mathematics, Physics and Informatics, Comenius University, Bratislava.

9. SOLOW, R. M. 1974. Intergenerational Equity and Exhaustible Resources. The Review of Economic Studies, Vol. 41 (symposium issue), 29-45.

10. STIGLITZ, J. 1974. Growth with Exhaustible Natural Resources: Efficient and Optimal Growth Paths. The Review of Economic Studies, Vol. 41 (symposium issue), 123-137.

11. WITHAGEN, C., ASHEIM, G. 1998. Characterizing Sustainability: The Converse of Hartwick's Rule, Journal of Economic Dynamics and Control, Vol. 23, 159-165.

12. YANO, K., ISHIHARA, S. 1973. Tangent and Cotangent Bundles. M. Dekker Inc New York. 